\title{
FERTILIZATION OF GOLDEN HAMSTER EGGS IN THE UTERUS
}

\author{
H. MIYAMOTO* AND M. G. CHANG \\ Worcester Foundation for Experimental Biology, \\ Shrewsbury, Massachusetts 01545, U.S.A.
}

(Received 12th February 1973)

\begin{abstract}
Summary. Sperm penetration was not observed when newly ovulated eggs, together with spermatozoa suspended in Tyrode's solution, were deposited into uteri of hamsters. When epididymal spermatozoa preincubated for 1 to $3 \mathrm{hr}$ in Tyrode's solution containing an equal volume of heated serum were used, 4 to $11 \%$ of eggs were penetrated 5 to $7 \mathrm{hr}$ later, but signs of egg degeneration were observed.
\end{abstract}

Fertilization of mammalian eggs normally takes place in the ampullary region of the oviducts and one wonders whether or not eggs can be fertilized in the uterus. From clinical observations, it appears that human eggs could be fertilized in the uterus and develop because a small number of pregnancies were reported following the transplantation of human ovary into the uterus and subsequent coitus (Estes, 1924; Estes \& Heitmeyer, 1934; Preston, 1953; von Ikle, 1961). In the rabbit, however, pregnancy failed following the transplantation of ovary into the uterus and subsequent copulation (Heitmeyer, 1934). It has been reported further that when newly ovulated rabbit eggs were transferred into the uterus of mated or inseminated rabbits, fertilization could take place but degeneration of eggs soon occurred (Chang, 1955; Bedford, 1969). In the golden hamster, fertilization failed and signs of egg degeneration were seen when recently ovulated eggs were transferred into the uterus of mated or inseminated hamsters (Hunter, 1968). This paper reports the fertilization of a small proportion of hamster eggs following their deposition into the uterus of hamsters with spermatozoa preincubated in Tyrode's solution containing an equal volume of heated blood serum.

Mature male and female golden hamsters were kept in a temperaturecontrolled room $\left(22 \pm 2^{\circ} \mathrm{C}\right)$ and exposed to $12 \mathrm{hr}$ light daily from 07.00 hours to 19.00 hours. Female animals were examined daily for the appearance of the post-oestrous discharge (Day 1) and only animals exhibiting a regular 4-day cycle were used. Eggs were flushed from the oviducts with Tyrode's solution on the morning of Day 1 or, more often, from females killed 15 to $17 \mathrm{hr}$ after being induced to superovulate by the injection of HCG (Yanagimachi \& Chang, 1964). A sperm mass was obtained either from the uterus of a hamster mated $\frac{1}{2}$ to $1 \mathrm{hr}$ previously or from the cauda epididymidis of a mature male. The

\footnotetext{
* Present address: Laboratory of Animal Reproduction, College of Agriculture, Kyoto University, Kyoto, Japan.
} 
mass was then placed either in $2 \mathrm{ml}$ Tyrode's solution or in $2 \mathrm{ml}$ Tyrode's solution containing an equal volume of hamster blood serum (at $56^{\circ} \mathrm{C}$ for $60 \mathrm{~min}$ ) and the samples were used immediately after preparation or preincubated for 1 to $3 \mathrm{hr}$ at $38^{\circ} \mathrm{C}$ in a $5 \% \mathrm{CO}_{2}$ incubator. Most of the recipient females used for the fertilization experiments were at the stage of the morning of Day I, but a number were at various different stages of the oestrous cycle. They were anaesthetized with Nembutal and their uterine horns were exposed. The recovered eggs with their mucus clot, together with about $0.2 \mathrm{ml}$ sperm suspension, were picked up with a fine glass pipette and deposited into each uterine horn. The utero-cervical junction was ligated to prevent the escape of eggs. The recipient animals were killed 5 to $7 \mathrm{hr}$ later and the uterine horns were flushed with Tyrode's solution for the recovery of eggs. The eggs were then examined to determine whether or not they had been penetrated and were undergoing fertilization (Miyamoto \& Chang, 1973).

Table 1. Fertilization of hamster eggs transferred into the uterus with preincubated spermatozoa

\begin{tabular}{|c|c|c|c|c|c|c|}
\hline $\begin{array}{l}\text { Medium for } \\
\text { suspending } \\
\text { spermatozoa }\end{array}$ & $\begin{array}{l}\text { Spermatozoa } \\
\text { from }\end{array}$ & $\begin{array}{l}\text { Period of } \\
\text { preincubation } \\
\text { of sperm. } \\
(\mathrm{hr})\end{array}$ & $\begin{array}{l}\text { No. of } \\
\text { females } \\
\text { used for } \\
\text { fertilization }\end{array}$ & $\begin{array}{l}\text { No. of } \\
\text { eggs } \\
\text { recovered }\end{array}$ & $\begin{array}{c}\text { No. of } \\
\text { penetrated } \\
\text { eggs }(\%)\end{array}$ & $\begin{array}{l}\text { No. of eggs } \\
\text { with enlarged } \\
\text { sperm head or } \\
\text { pronuclei }(\%)\end{array}$ \\
\hline $\begin{array}{l}\text { Tyrode's } \\
\text { solution }\end{array}$ & $\begin{array}{l}\text { Uterus } \\
\text { Epididymis }\end{array}$ & $\begin{array}{c}0 \\
2 \frac{1}{2} \text { to } 3\end{array}$ & $\begin{array}{l}8 \\
5\end{array}$ & $\begin{array}{r}99 \\
118\end{array}$ & $\begin{array}{l}0 \\
0\end{array}$ & $\begin{array}{l}0 \\
0\end{array}$ \\
\hline Tyrode's & Uterus & 0 & 9 & 95 & $2(2 \cdot 1)$ & $2(2 \cdot 1)$ \\
\hline $\begin{array}{l}\text { with heated } \\
\text { serum }\end{array}$ & $\begin{array}{l}\text { Epididymis } \\
\text { Epididymis }\end{array}$ & $\begin{array}{l}1 \text { to } 1 \frac{1}{2} \\
2 \frac{1}{2} \text { to } 3\end{array}$ & $\begin{array}{l}14 \\
14\end{array}$ & $\begin{array}{l}193 \\
314\end{array}$ & $\begin{array}{r}8(4 \cdot 1) \\
36(11 \cdot 5)\end{array}$ & $\begin{array}{r}5(2 \cdot 6) \\
32(10)\end{array}$ \\
\hline
\end{tabular}

Eggs were recovered 5 to $7 \mathrm{hr}$ after transfer and examined.

All the eggs were free from cumulus oophorus and corona radiata at the time of recovery. From the results presented in Table 1 , it can be seen that no egg was penetrated either by uterine spermatozoa or by epididymal spermatozoa that had been preincubated in Tyrode's solution for $2 \frac{1}{2}$ to $3 \mathrm{hr}$, but $2 \%$ of eggs were penetrated when spermatozoa recovered from the uterus and suspended in serum-Tyrode's solution were immediately used. Following the insemination with epididymal spermatozoa preincubated in the same medium for 1 to $1 \frac{1}{2} \mathrm{hr}, 4 \%$ of eggs were penetrated and $12 \%$ of eggs were penetrated after preincubation for $2 \frac{1}{2}$ to $3 \mathrm{hr}$. By examination of the detailed records, it was noted that the proportion of penetrated eggs was lower ( 1 to $3 \%$ ) in the recipient females on Day 1 than in those 2 to 4 days after ovulation ( 4 to $19 \%$ ), showing that the inhibition of fertilization may be more severe in the uterus on Day 1 than on Days 2 to 4 . The proportion of eggs with enlarged sperm heads $(91 \%)$ was much higher than that with pronuclei $(9 \%)$ and many eggs were degenerating after 5 to $7 \mathrm{hr}$ in the uterus, indicating a rapid deterioration of eggs before the formation of pronuclei, although a few polyspermic eggs and eggs with several supplementary spermatozoa were found.

The capacitation of hamster epididymal spermatozoa in the presence of 
blood serum for fertilization of eggs in vitro has been reported (Yanagimachi, 1970). The possibility of fertilization by epididymal spermatozoa preincubated for 1 to $3 \mathrm{hr}$ in Tyrode's solution containing heated serum shows again that capacitation can be better achieved in the presence of serum. Owing to the deleterious effect of the uterine environment on recently ovulated eggs, however, the chance of fertilization in the hamster uterus is still very low. In view of the possibility of fertilization of rabbit eggs in the uterus, albeit with subsequent rapid degeneration (Chang, 1955; Bedford, 1969; Adams, 1970; Glass, 1972), and the difficulty of fertilization of hamster eggs in the uterus reported by Hunter (1968) and in the present study, the possibility of fertilization and development of human eggs in the uterus requires further investigation.

This work was supported by a grant (HD 03003) from the U.S.P.H.S. and a grant from the Ford Foundation.

\section{REFERENCES}

Adams, G. E. (1970) Egg-uterus interrelationships. In: Advances in the Biosciences, Vol. 4, p. 149. Ed. G. Raspé. Pergamon Press, London.

BEDFORD, J. M. (1969) Limitations of the uterus in the development of the fertilizing ability (capacitation) of spermatozoa. F. Reprod. Fert. Suppl. 8, 19.

Chang, M. G. (1955) Développement de la capacité fertilisatrice des spermatozoides du lapin à l'interieur du tractus génital femelle, et fécondabilité des aufs de lapine. In: La Function Tubaire et ses Troubles, p. 40. Masson and Gie, Paris.

Estes, W. L., JR (1924) Ovarian implantation. Surgery Gynec. Obstet. 38, 394.

Estes, W. L., JR \& Heitmeyer, P. L. (1934) Pregnancy following ovarian implantation. Am. F. Surg. 24, 563.

Glass, R. H. (1972) Fate of rabbit eggs fertilized in the uterus. 7. Reprod. Fert. 31, 139.

Heitmeyer, P. L. (1934) Pregnancy following ovarian implantation: experimental investigation. Am. J. Surg. 24, 571.

Hunter, R. H. F. (1968) Attempted fertilization of hamster eggs following transplantation into the uterus. F. exp. Zool. 168, 511.

Mryamoto, H. \& Ghang, M. C. (1973) The importance of serum albumin and metabolic intermediates for capacitation of spermatozoa and fertilization of mouse eggs in vitro. 7. Reprod. Fert. 32, 193.

PRESTON, P. G. (1953) Transplantation of the ovary into the uterine cavity for the treatment of sterility in women. 7. Obstet. Gynaec. Br. Emp. 60, 862.

von IKLE, F. A. (1961) Schwangerschaft nach Implantation des Ovars in den Uterus. Gynaecologia, 151, 95.

YANAGIMAGH, R. (1970) In vitro capacitation of golden hamster spermatozoa by homologous and heterologous blood sera. Biol. Reprod. 3, 147.

Yanagmachi, R. \& Chang, M. G. (1964) In vitro fertilization of the golden hamster ova. F. exp. Zool. 156,361 . 